\title{
ORAL TETRACYCLINE PHOSPHATE COMPLEX (TETREX) IN THE TREATMENT OF NON-SPECIFIC URETHRITIS*
}

\author{
BY
}

\author{
E. B. WIJETUNGA AND R. S. MORTON \\ Royal Hospital, Sheffield
}

The role of the tetracyclines is well established in the treatment of non-specific urethritis (NSU). This paper reports a 'trial of orally-administered tetracycline phosphate complex (Tetrex), a combination of acidified sodium hexametaphosphate with acidified tetracycline hydrochloride in the ratio of 3:1. This preparation is said to be absorbed from the alimentary tract more efficiently than the hydrochloride combination and to give blood concentrations twice as high (Shidlovsky, Prigot, Maynard, Felix, and Hjelt-Harvey, 1958). These properties, it is claimed, give the phosphate complex an advantage over other tetracycline analogues in that effective blood levels can be maintained with a 12-hour dosage regimen (Olon and Holvey, 1968). The promised advantages of ease of administration and convenience to the patient, together with the experience of one of us (Statham and Morton, 1968) in the use of Tetrex PMT, a parenteral preparation of rolitetracycline nitrate, led us to believe that a trial of oral tetracycline phosphate complex should be undertaken.

\section{Patients Studied}

The series consisted of $\mathbf{4 8}$ male patients with NSU, the only basis of selection being the probability of return for surveillance. The average age was 27 years (range 17 to 49). Five of seventeen married men denied extra-marital risk of infection. A history of previous urethritis was given by $28 \mathrm{men}$; six had had gonorrhoea and NSU, seven gonorrhoea only, and fifteen NSU only. The estimated incubation period was 10 days or less in seven; more than 10 days in 25, and doubtful in sixteen. In nine cases the duration of the discharge had been longer than 10 days. The discharge was mucoid in nine, mucopurulent in 33, purulent in five, and not noted in one. The first glass only of the twoglass urine test showed a haze of pus in nineteen cases; in a further five cases, both glasses showed haze due to pus; in others the urine was clear with fine flocculations in the first glass or no specimen was made available for examination.

*Received for publication, July 24, 1968

\section{Management}

Gonorrhoea was excluded by Gram-stained smears and by culture, and trichomoniasis by wet film and culture.

Tetrex was given orally in a dosage of $500 \mathrm{mg}$. every 12 hours for 4 days.

The patients were asked to return for examination on the 3rd, 7th, 14th, 28th, 60th, and 90th day. In fact ten completed 2 to 3 months' surveillance, 22 completed 1 to 2 months, 32 completed 14 to 28 days, 42 made at least two return visits, and 43 at least one. Five patients did not re-attend for any follow-up.

\section{Results}

Successful response to treatment was defined as the absence of urethral discharge together with a macroscopically clear urine. Of the 48 patients treated, 42 were observed to have responded satisfactorily, giving a success rate of 87 per cent.; the five patients who did not return after treatment are not classed as successes. The one case of definite treatment failure occurred in a patient who had had three previous attacks of NSU. Two men whose urethritis had responded initially suffered recurrences, one with epididymitis, within 14 to 28 days after treatment. A further six cases recurred after the 28 th day. This is an overall recurrence rate of 17 per cent.

No side-effects of the drug were reported.

\section{Discussion}

The assessment of response to treatment in cases of NSU is rendered difficult by the lack of a clearly defined cause of the condition, by its variable presentation, and by its tendency to recur. There is little doubt, however, that some antibiotics do modify the disease both strikingly and promptly, and it is widely agreed that the tetracyclines fall into this category. In these circumstances we have felt it permissible to dispense with a comparable number of control cases. 
A response rate of 87 per cent. compares well with results reported after the use of other tetracycline preparations (Willcox, 1953, 1955; Morton and Read, 1957; Doyle, Gill, and Laird, 1957; Csonka and Rosedale, 1962).

The one known case of failure was associated with a feature noted as being of common occurrence in patients failing to respond (Csonka and Rosedale, 1962), i.e. a previous history of NSU and previous failure to respond to treatment.

The recurrence rate during surveillance is high. Perhaps this is not surprising. Morton and Read (1957) noted that the more immediately effective the form of treatment prescribed in NSU the higher was the recurrence rate.

\section{Summary and Conclusions}

(1) Tetracycline phosphate complex was given orally in a dose of $500 \mathrm{mg}$. 12-hourly for 4 days in 48 cases of non-specific urethritis.

(2) The type of patient, their history, and their clinical presentation were representative.

(3) Treatment was successful in 42 cases (87 per cent.) and there were no complaints of side-effects.

(4) These results compare favourably with those reported to have been obtained with other tetracyclines.

(5) It is concluded that, with its relative ease of administration, good therapeutic results, and absence of side-effects, tetracycline phosphate complex is well worth considering as a routine treatment in NSU.

We are pleased to acknowledge the help of our clinic staff under $\mathrm{Mr}$ W. E. Shaw, S.R.N., and the gift of tetracycline phosphate complex (Tetrex) from Bristol Laboratories Ltd.

\section{REFERENCES}

Csonka, G. W., and Rosedale, N. (1962). Brit. $\mathcal{F}$. vener. Dis., 38, 157.

Doyle, J. O., Gill, A. J., and LaIRD, S. M. (1957). Ibid., 33, 100.

MORTON, R. S., and READ, L. (1957). Ibid., 33, 223.

Olon, L. P., and Holvey, D. N. (1968). Clin. Med., 75 (1), 33.

Shidlovsky, B. A., Prigot, A., Maynard, A. De L., Felix, A J., and HJelt-Harvey, I. (1958). "Antibiotics Annual, 1957-58", p. 459.

StATHAM, R., and MORTON, R. S. (1968). Brit. F. vener. Dis., 44, 228.

Willcox, R. R. (1953). Ibid., 29, 225.

- (1955). Ibid., 31, 89.

Le phosphate de tétracycline complexe (Tetrex) par voie buccale dans le traitement de l'urétrite non-spécifique

\section{Résumé et Conclusions}

(1) Le phosphate de tétracycline complexe a été donné par voie buccale à la dose de $500 \mathrm{mg}$. à intervalles de 12 heures pendant quatre jours à 48 cas d'urétrite non-spécifique.

(2) Le genre de malade, son historique et sa présentation clinique étaient représentatifs.

(3) Le traitement avait réussi chez 42 cas (87 pour cent) et il n'y avait pas eu de remarques faites à propos d'effets toxiques.

(4) Ces résultats se comparent favorablement a ceux rapportés comme ayant été obtenus avec d'autres tétracyclines.

(5) Il est conclue que le phosphate de tétracycline complexe méritent bien d'être considéré comme traitment de routine dans l'urétrite non-spécifique vu son administration relativement aisée, çes bons résultats thérapeutiques et l'absence d'effets toxiques. 